\title{
Kilka słów o systemie szkolnictwa w Finlandii
}

\begin{abstract}
A few words about the school system in Finland
The article describes the structure and the key assumptions of the education system in Finland, taking into account the characteristics of each separate level of education. The author compares the Finnish and the Polish school systems in order to to determine whether and what elements could be used to enhance education in Poland. This problem seems to be particularly relevant in the light of the current debates about the education reform in Poland. The article can be treated as a voice in the discussion on the future shape of Polish education.
\end{abstract}

Key words: education, school system in Finland, Polish school system, education reform

Słowa klucze: edukacja, system szkolnictwa w Finlandii, polski system szkolnictwa, reforma edukacji

\section{Wprowadzenie}

Ze względu na wysokie miejsca zajmowane w ostatnich dwóch dekadach przez fińskich uczniów w testach PISA ${ }^{1}$, system edukacji w Finlandii stał się obiektem zainteresowania mediów na całym świecie. Pojawiło się wiele artykułów prasowych (m.in. Postoła 2016; Pilarska 2013), publikacji naukowych (m.in. Sahlberg 2011a i 2011b; Jagiełło-Rusiłowski 2011; Musiał 2014 i 2015) oraz programów telewizyjnych przedstawiających fińskie szkolnictwo jako zjawisko godne uwagi, a niejednokrotnie - wzór do naśladowania. Niekiedy informacje podawane w programach telewizyjnych i tekstach nienaukowych publikowanych w Internecie są wybierane głównie ze względu na „medialność” materiału. Zasady panujące na

\footnotetext{
${ }^{1}$ PISA (Programme for International Student Assessment), czyli Badanie Programu Międzynarodowej Oceny Uczniów, koordynowane przez Organizację Współpracy Gospodarczej i Rozwoju, to obecnie największe badanie edukacyjne na świecie. Przeprowadza się je co trzy lata, począwszy od 2000 r., w celu określenia stopnia przygotowania 15-latków do dalszej edukacji, wymagań rynku pracy i powodzenia w dorosłym życiu. Badanie PISA dotyczy trzech dziedzin: czytania i interpretacji, matematyki oraz rozumowania w naukach przyrodniczych.
} 
danym poziomie edukacji zostają uogólnione do wszystkich typów szkół i rzadko wspomina się o problemach fińskiego szkolnictwa, co daje uproszczony obraz „niedoścignionego ideału” i często prowadzi do konkluzji, że w innych krajach tego typu system się nie sprawdzi ze względu na uwarunkowania społeczne.

Sukces fińskiego szkolnictwa jest szczególnie interesujący, ponieważ nie zawsze należało ono do światowej czołówki i mało kto spodziewał się, że po reformie, która rozpoczęła się w latach 70 . ubiegłego stulecia, w niewielkim kraju na północy Europy w pierwszych dekadach XXI wieku uczniowie będą osiągać tak świetne rezultaty. Jednym z najważniejszych czynników, które przyczyniły się do sukcesu Finów w sferze edukacji, jest fakt, że celem reformy nie było osiągniecie przez fińskie szkolnictwo wysokich miejsc w rankingach, lecz stworzenie systemu uwzględniającego potrzeby uczniów, postulaty psychologii rozwojowej, uwarunkowania społeczno-kulturowe kraju i dobrze przygotowywanie dzieci do dorosłego życia.

Zasadnym wydaje się opis kluczowych założeń systemu edukacji w Finlandii z uwzględnieniem oddzielnej charakterystyki każdego poziomu nauczania, porównanie go z polskim systemem edukacji oraz próba określenia, czy i jakie elementy możemy wykorzystać w budowaniu lepszego szkolnictwa w Polsce. Problem ten wydaje się szczególnie aktualny w świetle licznych debat dotyczących bieżącej reformy edukacji. Artykuł może być traktowany jako głos w dyskusji o kształcie polskiego szkolnictwa.

\section{Fiński system szkolnictwa - struktura}

Obecnie w fińskim szkolnictwie można wyodrębnić następujące etapy kształcenia:

1. Wczesna edukacja i opieka nad dziećmi przed rozpoczęciem obowiązku szkolnego.

2. Obowiązkowa edukacja przedszkolna dla sześciolatków w roku poprzedzającym rozpoczęcie nauki.

3. Dziewięcioletnie obowiązkowe kształcenie na poziomie podstawowym (fiń. peruskoulu) podzielone na sześć lat szkoły podstawowej i trzy lata szkoły średniej niższego szczebla, opcjonalny dziesiąty rok nauki.

4. Wykształcenie średnie ogólne lub zawodowe.

5. Wykształcenie wyższe prowadzone przez uniwersytety i uniwersytety nauk stosowanych.

Co ważne, wszystkie etapy kształcenia dostępne są również dla osób dorosłych, które mogą uczęszczać do różnych centrów edukacyjnych oraz uniwersytetów letnich. 


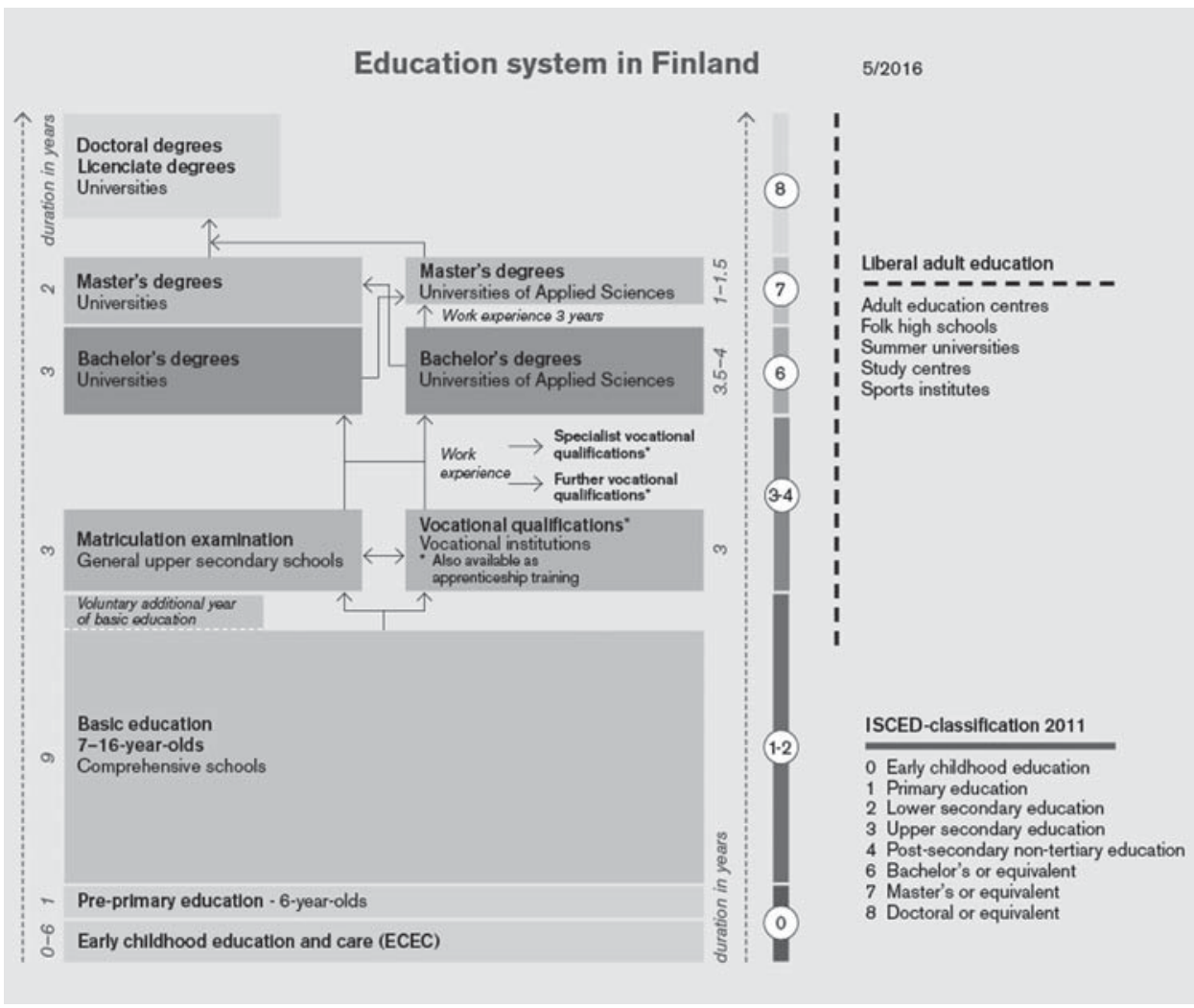

Rysunek 1. System Edukacji w Finlandii

Źródło: oficjalna strona Ministerstwa Edukacji w Finlandii.

\section{Edukacja przedszkolna i wczesnoszkolna}

Na poziomie nieobowiązkowej wczesnej edukacji dostępne są żłobki i punkty opieki dla dzieci do piątego roku życia. W placówkach państwowych oferowany jest bezpłatny ciepły posiłek dla wszystkich podopiecznych. Poprzez wsparcie finansowe ze strony państwa fińskie mamy są zachęcane do opiekowania się w domu dziećmi do trzeciego roku życia. Nauczyciele edukacji przedszkolnej mają z reguły stopień licencjata (Ahtola i Niemi 2014: 138).

Od 2015 roku wszystkie fińskie dzieci w wieku sześciu lat mają obowiązek uczęszczania do bezpłatnej klasy przygotowawczej (Ministerstwo Edukacji Finlandii). Wcześniej obligatoryjna edukacja w Finlandii rozpoczynała się w wieku siedmiu lat, jednak większość dzieci korzystała z darmowej „zerówki” (Ahtola i Niemi 2014: 137).

W Finlandii edukacja od klasy przygotowawczej jest bezpłatna na wszystkich poziomach kształcenia. Nie dotyczy to jedynie samego nauczania, ale również 
podręczników, przyborów szkolnych i posiłków spożywanych w stołówce. Szkoły prywatne w Finlandii należą do rzadkości i najczęściej posiadają określony profil pedagogiczny, na przykład placówki Montessori czy Steinera (por. Postoła 2016). Co ciekawe, są dofinansowywane przez państwo i również nie pobierają czesnego. Annarilla Ahtola i Pekka Niemi podkreślają, że w Finlandii edukację uważa się za jedno z podstawowych praw obywatelskich, a głównym zadaniem szkolnictwa jest udostępnienie wszystkim obywatelom jak najlepszego wykształcenia: „A major objective is to achieve as high a level of education and competence as possible for the whole population, and post-compulsory education is offered to whole age groups" (Ahtola i Niemi 2014: 137).

Pierwszy etap obowiązkowej edukacji szkolnej w ramach peruskoulu trwa sześć lat (fiń. alakoulu lub ala-aste), przy czym większość zajęć prowadzona jest przez jednego nauczyciela przez wszystkie lata, a klasy liczą średnio od 15 do 20 uczniów. Nie ma podziału na przedmioty ważniejsze i mniej ważne, dzieci uczestniczą w licznych zajęciach praktyczno-technicznych, a na przerwach wychodzą na świeże powietrze. Prace domowe są zadawane, ale z założenia nie powinny mieć zbyt wysokiego poziomu trudności i zajmować uczniom więcej niż około trzy godziny w tygodniu. Uczniowie nie piszą ujednoliconego ogólnokrajowego testu na koniec szóstej klasy i nie prowadzi się rankingu najlepszych szkół podstawowych.

$\mathrm{Z}$ tego powodu prawie wszyscy uczniowie uczęszczają do szkoły znajdującej się najbliżej miejsca zamieszkania. Ani placówek oświatowych, ani klas nie dzieli się na lepsze czy gorsze - dzieci z założenia powinny uczyć się wśród rówieśników o różnych zdolnościach i zainteresowaniach. Na tym etapie kształcenia praktykuje się ocenianie opisowe. Od uczniów z najlepszymi wynikami w nauce oczekuje się udzielania pomocy słabszym kolegom. Co więcej, dużą uwagę skupia się na wychwyceniu dzieci z problemami w nauce, jak najszybszym zdiagnozowaniu przyczyny i wczesnej interwencji. Uwidaczniają się tu wartości powszechne w Skandynawii, różniące się w znacznym stopniu od tych propagowanych w krajach anglosaskich. Rywalizacja poszczególnych szkół, rankingi, standaryzowane testy, porównywanie uczniów i nastawienie na sukces jednostki - tak powszechne w Wielkiej Brytanii czy Stanach Zjednoczonych - w Finlandii zostały zastąpione przez nastawienie na wspólną pracę i wyrównywanie szans. Przykład Finlandii pokazuje, jak ważne jest uwzględnienie systemu aksjologicznego danego społeczeństwa przy budowaniu systemu szkolnictwa, który „sprawdzi się" w danym kraju.

Wyżej wymienione działania przyczyniły się do tego, że Finlandia należy do krajów o najmniejszym odsetku uczniów z bardzo niskimi wynikami w nauce. To właśnie w wyrównywaniu szans i zapewnieniu wysokiego poziomu nauczania wszystkim dzieciom często widzi się przyczyny sukcesu fińskiego szkolnictwa (por. Sahlberg 2011a: 45-46). 
Warto zwrócić uwagę na trend panujący obecnie w Polsce. W gazetach i Internecie publikowane są rankingi najlepszych placówek oświatowych, przy czym w ostatnich latach we wszystkich województwach czołowe pozycje wśród szkół podstawowych zajmują płatne placówki prywatne lub społeczne. Rankingi zdają się wspomagać szkoły prywatne, w których w małych grupach uczą się jedynie dzieci z zamożnych domów i do których rzadko przyjmowani są uczniowie z problemami w nauce. Do wielu prywatnych szkół podstawowych trzeba zdać egzamin. Świetne efekty osiągane przez tak wyselekcjonowanych uczniów nie są niespodzianką, jednak rodzice oglądający ranking otrzymują jedynie informację o średnim wyniku testu, a nie o postępach poszczególnych uczniów. Szkoły państwowe w Polsce również coraz częściej przyjmują dzieci spoza rejonu, aby lepiej wypaść w rankingach i przyciągnąć lepszych uczniów.

W ten sposób pogłębiają się różnice w poziomie poszczególnych placówek, a dzieci nie uczęszczają do najbliższej szkoły, ale są dowożone do tych o lepszej reputacji czy wyższym miejscu w rankingu. Rodzi to jeszcze jeden problem system zmianowy, który nie jest zjawiskiem pożądanym, zwłaszcza na wczesnym etapie kształcenia.

Wydaje się, że zmniejszenie liczby uczniów w klasach w szkołach państwowych i co za tym idzie zindywidualizowane podejście do ucznia oraz ograniczenie możliwości przyjmowania dzieci spoza rejonu (np. jeśli wiąże się to z koniecznością wprowadzania systemu zmianowego) mogłoby ograniczyć „odpływ” najlepszych uczniów do placówek prywatnych. Jednocześnie należy pamiętać o tym, że stratyfikacja wśród placówek oświatowych jest również wyrazem pogłębiających się różnic majątkowych w społeczeństwie, więc zapobieganie jej jest procesem złożonym i niełatwym, zależnym nie tylko od samego systemu edukacji. Niewielki procent uczniów osiągających w Finlandii bardzo słabe wyniki w nauce z reguły łączy się nie tylko z samym systemem szkolnictwa, ale również z płaską strukturą społeczeństwa i istnieniem bardzo licznej klasy średniej (por. Sahlberg 2011a: 45).

\section{Fińskie gimnazjum (yläkoulu lub yläaste)}

Po ukończeniu pierwszego etapu edukacji nauka kontynuowana jest ramach w peruskoulu, jednak często uczniowie klas 7-9 (fiń. yläkoulu lub yläaste) uczą się w oddzielnym budynku. Yläkoulu posiada własną dyrekcję, można więc powiedzieć, że jest to odpowiednik polskiego gimnazjum, które właśnie znika z polskiego szkolnictwa. Na tym etapie edukacji uczniowie nadal uczęszczają do najbliższej szkoły. Przed reformą oświaty zapoczątkowaną w 2017 roku w Polsce do najlepszych gimnazjów - najczęściej tworzonych przy prestiżowych 
liceach ogólnokształcących - przyjmowano uczniów, którzy osiągnęli najlepsze wyniki na sprawdzianie szóstoklasisty i dodatkowo zdali testy (niejednokrotnie $\mathrm{z}$ kilku przedmiotów). W ten sposób tworzono placówki dla wybranych, co w Finlandii nie jest praktykowane. Wydaje się, że postępująca stratyfikacja szkół nie jest pożądana na tym stosunkowo wczesnym etapie kształcenia, co wydają się potwierdzać niższe niż w edycjach wcześniejszych wyniki polskich uczniów w testach PISA w 2015 roku (por. strona internetowa polskiego MEN). Przywrócenie ośmioletnich szkół podstawowych może w pewnym stopniu powstrzymać ten proces i zatrzymać najlepszych uczniów w rejonowych szkołach, co wydaje się korzystne dla ogólnego poziomu nauczania i rozwoju kompetencji społecznych uczniów przebywających w zróżnicowanej, a nie wyselekcjonowanej grupie rówieśniczej.

W klasach 7-9 zajęcia prowadzą już nauczyciele przedmiotowi w różnych salach. Jak widać, przypomina to podejście stosowane w Polsce już od klasy czwartej. Uczniowie od ósmej klasy muszą już otrzymywać oceny (od 4 do 10), zaś stopnie na świadectwie ukończenia szkoły wpływają na wybór dalszej ścieżki edukacyjnej. Konkurs świadectw jest przejawem zaufania do nauczycieli i wiary w ich sprawiedliwe ocenianie. Wydaje się, że brak egzaminów do szkoły średniej lub pełniących podobną funkcję testów na zakończenie poprzedniego etapu edukacji nie jest rozwiązaniem, które polscy rodzice i uczniowie mogliby zaakceptować ze względu na panujące w społeczeństwie przeświadczenie o niesprawiedliwości oceniania przez nauczycieli.

Do połowy lat 80. ubiegłego stulecia dzieci w klasach 7-9 na niektórych przedmiotach (matematyka, język obcy) dzielone były na grupy o trzech poziomach zaawansowania w zależności od wcześniej zdobytych umiejętności, co przyczyniało się do zwiększenia zróżnicowania wyników nauczania (Sahlberg 2011a: 22). Obecnie nie praktykuje się tworzenia grup silniejszych i słabszych uczniów, a oczekiwania są takie same wobec wszystkich dzieci.

Bardzo ciekawym rozwiązaniem jest możliwość pozostania jeszcze przez rok w peruskoulu w dziesiątej klasie, bez jednoczesnego stygmatyzowania uczniów, którzy dokonają takiego wyboru. Jeśli zachodzi potrzeba, nastolatek może spożytkować taki rok na nadrobienie ewentualnych zaległości lub przemyślenie decyzji dotyczącej dalszego etapu kształcenia.

Po yläkoulu kończy się obowiązkowy okres nauki i uczniowie stają przed wyborem dalszej ścieżki życiowej. W podjęciu prawidłowej decyzji dotyczącej dalszej edukacji pomaga obowiązkowe doradztwo zawodowe (Sahlberg 2011a: 23). Mimo to stosunkowo duża grupa (np. w 2012 r. - 13\% młodzieży w wieku 15-19 lat) nie podejmuje lub rezygnuje $\mathrm{z}$ dalszej edukacji, co uważane jest za jedną z największych bolączek fińskiego szkolnictwa (por. Ahtola i Niemi 2014; Sahlberg 2011a: 28). 


\section{Szkoły średnie zawodowe i ogólnokształcące}

Około 50\% absolwentów peruskoulu kontynuuje naukę w szkołach zawodowych, które oprócz przedmiotów ogólnokształcących oferują praktykę zawodową i naukę przedmiotów bezpośrednio związanych z wybraną profesją, a około $40 \%$ - w szkołach ogólnokształcących (Sahlberg 2011a: 26; MEF 2017). Szkolnictwo zawodowe jest atrakcyjne, ponieważ pozwala na zdobycie wybranej profesji, odbycie praktyki i jednocześnie nie zamyka drogi do szkoły wyższej. Co ciekawe, uczniowie szkół zawodowych mogą uczęszczać jednocześnie do placówek ogólnokształcących na wybrane przedmioty.

W 1985 roku we wszystkich szkołach średnich wprowadzone zostało nauczanie modułowe $\mathrm{z}$ obowiązkowym sprawdzianem zdobytych kompetencji na koniec każdego modułu. Rok szkolny nie jest podzielony na semestry, ale na sześcio-, siedmiotygodniowe kursy, które nie są przypisane ani do konkretnej klasy, ani do grupy wiekowej, co daje uczniom dużą autonomię. Aby zostać absolwentem ogólnokształcącej szkoły średniej, należy ukończyć 75 kursów, z których około 2/3 jest obowiązkowa. Uczniowie z reguły zaliczają więcej, bo średnio 80-90 kursów (por. Sahlberg 2011a: 25-28).

Paula Pilarska, która odwiedziła jedną z fińskich szkół średnich przygotowujących do matury międzynarodowej IB, Vasa övningsskola, opisała system sprawdzania wiedzy w szkołach średnich:

Przez tydzień od poniedziałku do piątku uczniowie przychodzą do szkoły na godzinę 9 i codziennie piszą sprawdzian $z$ innego przedmiotu, który obejmuje wiadomości z ostatniego modułu. Przez kolejne trzy dni po weekendzie uczniowie przychodzą według planu zajęć, ale nie mają zwykłych lekcji, tylko spotkania z nauczycielami, poświęcone omówieniu testów. Następne cztery dni są wolne, a od poniedziałku rozpoczyna się nowy moduł. Tak więc po trzech latach nauki uczniowie mają kilkadziesiąt ocen $\mathrm{z}$ testów. W sumie na koniec trzeciej klasy każdy uczeń powinien mieć zaliczone 75 sprawdzianów (Pilarska 2013).

Absolwenci wszystkich szkół średnich (zawodowych i ogólnokształcących) mają prawo do kontynuowania nauki i otrzymania wyższego wykształcenia. Aby dostać się na uniwersytet lub do wyższej szkoły zawodowej, uczeń szkoły ogólnokształcącej musi napisać ujednolicony egzamin krajowy, od którego wyników zależy, jaki kierunek studiów może wybrać. Absolwenci szkół zawodowych mogą, ale nie muszą przystępować do egzaminu, jednak mają możliwość kontynuowania nauki na uczelni wyższej na podstawie otrzymanego certyfikatu o ukończeniu szkoły zawodowej (Sahlberg 2011a:31). Na niektóre kierunki (np. nauczycielskie) obowiązują dodatkowe egzaminy. Odsetek uczniów, którzy decydują się na kontynuację nauki po ukończeniu szkoły zawodowej, jest niższy aniżeli po ukończeniu szkoły ogólnokształcącej. 


\section{Uczelnie wyższe}

W Finlandii istnieją dwa typy uczelni wyższych - uniwersytety (wśród których znajdują się również uczelnie techniczne i artystyczne) i nieuniwersyteckie wyższe szkoły zawodowe, często nazywane politechnikami. Politechniki zaczęły powstawać dopiero w latach 90. XX w., są więc tworem stosunkowo nowym, którego zadaniem jest wspieranie rozwoju regionalnego dzięki dialogowi z lokalnym przemysłem i organizacjami pożytku publicznego (por. Jagiełło-Musiłowski 2011). Oba typy szkół są bezpłatne. Mimo rosnącej liczby politechnik, które są częścią szeroko pojętego szkolnictwa wyższego, „to uniwersytety stanowiły i w dalszym ciągu stanowią podstawową instytucję szkolnictwa wyższego w Finlandii” (por. Musiał 2015: 6).

W 2009 roku uniwersytety otrzymały większą autonomię i przestały służyć jako narzędzie administracji państwowej:

The reform made universities independent legal entities, which were to decide whether they would act as corporations of the public law or foundations of the private law. Autonomous universities have now got the right to decide about their strategic research directions, about possible mergers with other units, and they have been given more freedom in acquisition of research funds that can be used according to the development strategy accepted by the institution (Musiał 2014: 17-18).

Obecnie studenci większości kierunków najpierw otrzymują tytuł licencjata po trzyletnich studiach, a potem mogą kontynuować naukę na studiach magisterskich. Co ciekawe, aby dostać się na studia magisterskie w ramach politechniki, trzeba mieć co najmniej trzyletnie doświadczenie w zawodzie zgodnym z wybraną specjalnością.

Wydaje się, że w obecnej sytuacji w Polsce, kiedy bardzo wielu uczniów kończy licea ogólnokształcące, powstanie większej liczby wyższych szkół zawodowych mogłoby rozwiązać dylematy młodych absolwentów, którzy bardziej zainteresowani są zdobyciem praktycznych umiejętności aniżeli otrzymaniem pełnego wykształcenia uniwersyteckiego ${ }^{2}$.

\section{Cechy wyróżniające fiński system szkolnictwa}

Jednym z filarów szkolnictwa fińskiego jest wspominana już kilkukrotnie indywidualizacja procesu nauczania i dbałość o dobro wszystkich uczniów. O sposobach realizacji tego założenia napisał Adam Jagiełło-Rusiłowski:

$\overline{2}$ O sposobie finansowania szkolnictwa wyższego w Finlandii por. Musiał (2015). 
Troska o każdego ucznia jako osobowości, która zawsze ma coś do zaoferowania swojej społeczności i poprzez swoją postawę tak czy inaczej na nią wpływa, zachęca do poszukiwania spójnych z taką filozofią metod kształcenia. Są to od najwcześniejszych etapów edukacji metody aktywizujące, zadania otwarte, zespołowe, interdyscyplinarne, projekty badawczo-rozwojowe, symulacje, debaty i sesje doradztwa naukowego, webinaria czy warsztaty kreatywnego rozwiązywania problemów (Jagiełło-Rusiłowski 2011: 11).

Kolejnym czynnikiem pozytywnie wpływającym na jakość edukacji w Finlandii są doskonale przygotowani nauczyciele. Nie ma wątpliwości, że bez odpowiednio przygotowanej i zmotywowanej kadry pedagogicznej nie byłoby możliwe stworzenie dobrego systemu edukacji. W Finlandii nauczyciele są cenieni, szanowani i mają wysoką pozycję społeczną. Co roku o jedno miejsce na studiach dających uprawnienia pedagogiczne w szkołach podstawowych ubiega się około dziesięciu kandydatów, a na egzaminach sprawdza się predyspozycje do wykonywania zawodu:

Only Finland's best and brightest are able to fulfill those professional dreams. Every spring, thousands of high school graduates submit their applications to the departments of teacher education in Finnish universities. Usually it is not enough to have completed high school and passed a rigorous matriculation examination. Successful candidates must have not only good scores and excellent interpersonal skills, but also a deep personal commitment to teach and work in schools. Annually only about one in every ten applicants will be accepted to study to become a primary school teacher. Among all categories of teacher education (i.e., not just primary), about 5,000 prospective teachers are selected from about 20,000 applicants (Sahlberg 2011b: 35).

Nauczyciele prowadzą badania i nieustannie się rozwijają, mogą tworzyć programy nauczania, sami decydować o wyborze podręcznika lub nawet jego braku.

Praca nauczyciela w Finlandii przyciąga ambitnych, utalentowanych młodych ludzi ze względu na dobre zarobki, wysoki prestiż społeczny, stałą i pewną pracę, dużą autonomię w działaniu oraz możliwość rozwoju intelektualnego i podnoszenia kwalifikacji.

Trudno to samo powiedzieć o Polsce. Zarobki nauczyciela stażysty są niższe niż niewykwalifikowanych pracowników fizycznych, a w szkołach nie brakuje biurokracji. Klasy są stosunkowo duże, co utrudnia indywidualizację nauczania. W Polsce kierunki nauczycielskie nie są zbyt popularne, zwłaszcza wśród mężczyzn, właśnie ze względu na niskie zarobki. Niejednokrotnie aby zapewnić rodzinie przyzwoity poziom życia, nauczyciele muszą dorabiać korepetycjami lub pracować na dwóch etatach, co negatywnie odbija się na jakości prowadzonych zajęć i obniża motywację. $Z$ wyżej wymienionych powodów bardzo często najlepsi studenci nie decydują się na specjalizację nauczycielską, co nie pomaga w budowaniu autorytetu kadry pedagogicznej w społeczeństwie. Wydaje się, że bez znaczących podwyżek dla nauczycieli nie sposób podnieść ich autorytet ani 
pozycję społeczną, która w systemie kapitalistycznym ściśle związana jest z wysokością zarobków.

Kolejnym filarem fińskiego szkolnictwa są relacje budowane na zaufaniu. Anna Izabela Brzezińska i Tomasz Czub podkreślają rolę zaufania w szkolnictwie, omawiając problem kształtu polskiej edukacji: „Kiedy podstawą edukacji staną się oparte na wzajemnym zaufaniu relacje międzyludzkie, to szkoła będzie mogła stać się nie tylko kuźnią talentów, ale również ostoją kultury współpracy i wspólnotowości” (Brzezińska i Czub 2013: 41).

A to właśnie z zaufaniem i pewnością co do wysokich kompetencji kadry pedagogicznej wiążą się inne wyróżniające fiński system szkolnictwa cechy. Poszczególne szkoły cieszą się ogromną autonomią, szkolnictwo jest zdecentralizowane. Uczniowie nie piszą ogólnokrajowych sprawdzianów wiedzy i nie prowadzi się rankingu szkół. Nauczyciele sami tworzą program nauczania zgodny z podstawą programową i dostosowują go do lokalnych potrzeb. Nie ma narzuconych podręczników ani metodyki nauczania. Autonomia, którą otrzymują fińscy pracownicy szkolnictwa, i brak potrzeby kontroli wiążą się z tym, że nauczycielami zostają najlepsi absolwenci, a sami nauczyciele cieszą się wysokim poziomem zaufania społecznego. Wydaje się, że bez podniesienia prestiżu zawodu nauczyciela i indywidualizacji nauczania budowanie tego typu zaufania w Polsce może okazać się bardzo trudne.

\section{Podsumowanie}

Należy zaznaczyć, że fiński i polski system edukacji na etapie przedszkolnym wykazują duże podobieństwa i sprzyjają wyrównywaniu szans. Państwowe przedszkola z niewielkim czesnym, bezpłatna obowiązkowa zerówka, wydłużenie płatnego urlopu macierzyńskiego czy korzystanie przez matki z urlopu wychowawczego wszystko to wspomaga wczesny rozwój dzieci i umożliwia szybką diagnozę problemów edukacyjnych i wczesną interwencję.

Ograniczenie liczby testów ogólnokrajowych w aktualnej reformie edukacji wydaje się zasadne, zwłaszcza biorąc pod uwagę przykład fińskiego szkolnictwa, gdzie nie występuje niepożądana zbyt wczesna stratyfikacja szkół (a co za tym idzie uczniów).

W dyskusjach o reformie edukacji w Polsce w mediach na pierwszy plan wysuwa się nową podstawę programową i problem likwidacji gimnazjów. Choć są to bardzo ważne aspekty systemu kształcenia, ich zmiana najprawdopodobniej nie będzie wystarczająca, aby podnieść poziom nauczania i zmienić nastawienie rodziców, którzy nie darzą nauczycieli pełnym zaufaniem. Zasadnym wydaje się przemyślenie zmiany statusu nauczyciela w naszym społeczeństwie, próba przyciągnięcia do tego zawodu najlepszych. Tu fiński system edukacji może stać się 
wzorem dla niejednego kraju, także Polski. Dobre zarobki, pewne miejsce pracy i możliwość ciągłego rozwoju wydają się świetnym sposobem na przekonanie utalentowanych ludzi, że nauczanie to właśnie ta ścieżka, którą chcą podążać.

To pierwszy i niezbędny krok, aby w polskich szkołach pracowała zmotywowana kadra pedagogiczna, która będzie mogła rozpocząć budowę systemu edukacji opartego na zaufaniu oraz otrzymać większą autonomię bez obaw o obniżenie jakości kształcenia.

\section{Bibliografia}

Ahtola, A. i P. Niemi (2014). Does it work in Finland? School psychological services within a successful system of basic education. School Psychology International 35 (2): 136-151.

Brzezińska, A. i T. Czub (2013). Zaufanie społeczne jako wyzwanie i ratunek dla polskiego systemu edukacji. Nauka 1: 31-44.

Jagiełło-Rusiłowski, A. (2011). Fiński model kształcenia i oceniania kompetencji społecznych inspiracje dla polskich interesariuszy szkolnictwa wyższego. Warszawa: Instytut Badań Edukacyjnych.

Ministerstwa Edukacji Finlandii, http://minedu.fi/en/education-system (dostęp: 6.03.2017).

Musiał, K. (2014). Elitist turn in higher education in the context of recent reforms in the Nordic countries. CPP RPS 79.

Musiał, K. (2015). Reformy edukacji wyższej w Finlandii w obszarze finansowania szkół wyższych. Seria: Analizy IBE, 11. Warszawa: Instytut Badań Edukacyjnych.

Pilarska, P. (2013). Finlandia, czyli wzór edukacji. Psychologia w szkole 5.

Postoła, A. (2016). Jak się uczy w fińskiej szkole. Gazeta Wyborcza, 6 września 2016, http:// wyborcza.pl/1,145452,20645854,jak-sie-uczy-w-finskiej-szkole.html (dostęp: 1.08.2017).

Sahlberg, P. (2011a). Finnish Lessons: What Can the World Learn from Educational Change in Finland? Nowy Jork-Londyn: Teachers College, Columbia University.

Sahlberg, P. (2011b). Lessons from Finland. American Educator (Summer): 35-37. 